\title{
Struktur Populasi Gastropoda Terebralia palustris pada Ekosistem Mangrove Teluk Mandeh Kabupaten Pesisir Selatan
}

\author{
Population of Gastropod Terebralia palustris in Mangrove Ecosystem of \\ Mandeh Bay Pesisir Selatan Districts \\ Yozi Ahmad Fadhil $^{{ }^{*}}$, Syafruddin Nasution ${ }^{1}$, Elizal $^{1}$ \\ ${ }^{1}$ Jurusan Ilmu Kelautan, Fakultas Perikanan dan Kelautan, Universitas Riau \\ email:yoziahmadfadhil96@gmail.com
}

(Received: 10 Juni 2021; Accepted: 05 Juli 2021)

\begin{abstract}
ABSTRAK
Penelitian ini dilaksanakan pada bulan September 2020 di Ekosistem Mangrove Teluk Mandeh Kabupaten Pesisir Selatan yang bertujuan untuk mengetahui kepadatan, pola sebaran dan ukuran sebaran Terebralia palustris. Metode yang digunakan dalam penelitian ini adalah metode survei. Ada lima stasiun yang dipilih di ekosistem mangrove Mandeh. Hasil penelitian menunjukkan bahwa densitas dari 4,47 menjadi $6,8 \mathrm{ind} / \mathrm{m}^{2}$. Perbedaan densitas Terebralia palustris antar stasiun dianalisis menggunakan One way ANOVA. Hasil uji ANOVA diperoleh nilai signifikansi 0,036 ( $\mathrm{p}$ value $<0,05$ ) yang menggambarkan bahwa terdapat perbedaan densitas yang nyata dan nyata antar stasiun. Indeks pola sebarannya adalah $\mathrm{Id}=1$ yang artinya pola sebarannya acak.
\end{abstract}

Kata Kunci: Terebralia palustris, Struktur Populasi, Mangrove Teluk Mandeh

\begin{abstract}
This study was conducted in September 2020 in the Mangrove Ecosystem of Mandeh Bay, Pesisir Selatan Regency which aims to determine the density, distribution pattern and size distribution of Terebralia palustris. The study method used in this study was a survey method. There were five stations chosen at Mandeh mangrove ecosystem. The results showed that the density from 4,47 to $6,8 \mathrm{ind} / \mathrm{m}^{2}$. The difference in the density of Terebralia palustris among station was analyzed using One way ANOVA. The ANOVA test results obtained a significant value of 0.036 ( $\mathrm{p}$ value $<0.05$ ) which illustrates that there real differences significant difference in the density between stations. The distribution pattern index was $\mathrm{Id}=1$, which means that the distribution pattern is random.
\end{abstract}

Keyword: Terebralia palustris, Population Structure, Mangrove Teluk Mandeh

\section{Pendahuluan}

Gastropoda merupakan kelompok fauna yang paling dominan dari ketujuh kelas dalam filum Mollusca. Gastropoda memiliki anggota yang sangat beragam yang pada umumnya memiliki cangkang spiral menutupi tubuhya, kecuali pada beberapa anggota Opistobranchia (Islami, 2010). Gastropoda dapat ditemukan di seluruh dunia mulai dari perairan dangkal, berpasir, terumbu karang dan laut dalam (Holland, 2008).

Gastropoda pada umumnya akan naik ke pohon mangrove untuk menghindar dari pasang surut tetapi setelah air surut akan turun kembali untuk mencari makan. Selain itu juga ada yang menetap di substrat lumpur yaitu dengan menguburkan dirinya pada lumpur dengan membuat lubang pada tanah (Silaen $e t$ al., 2013). Sementara itu Wijayanti (2007) juga menjelaskan bahwa substrat di dasar perairan akan menentukan kelimpahan dan komposisi jenis dari hewan benthos. Jenis substrat dasar merupakan komponen yang sangat penting bagi kehidupan organisme benthos.

Menurut Silaen et al. (2013) kepadatan dan distribusi gastropoda dipengaruhi oleh lingkungan habitatnya, ketersediaan makanan, 
pemangsaan, dan juga kompetisi. Tekanan ekologis dan perubahan lingkungan seperti vegetasi mangrove dapat mempengaruhi kepadatan organisme tersebut.

Berdasarkan penelitan Rivai et al. (2018) ditemukan kepadatan gastropoda di Perairan Pantai Nirwana Sumatera Barat yang menyatakan bahwa gastropoda relatif melimpah pada substrat yang memiliki kandungan substrat pasir. Hirzan et al. (2017) menambahkan gastropoda pada ekosistem mangrove di Pulau Sarinda Padang Sumatera Barat bahwa gastropoda yang hidup pada kawasan mangrove berasosiasi dengan ekosistem mangrove sebagai tempat berlindung memijah dan juga sebagai suplai makan yang menunjang pertumbuhan gastropoda. Salah satu dari banyaknya spesies gastropoda yang ada di hutan mangrove Teluk Mandeh adalah Terebralia palustris (Dinas Kelautan dan Perikanan Kab. Pesisir Selatan, 2011).

Gastropoda jenis $T$. palustris merupakan gastropoda laut yang termasuk dalam keluarga Potamididae. Menurut Baharuddin et al. (2018) menyatakan bahwa Famili Potamididae merupakan kelompok moluska mangrove yang paling sering ditemukan di kawasan ekosistem mangrove karena kelompok ini termasuk moluska asli kawasan mangrove yang menyukai permukaan berlumpur seperti kondisi di kawasan mangrove Teluk Mandeh ini.

Budiman (2009) menyatakan bahwa T.palustris merupakan moluska asli hutan mangrove yang seluruh hidupnya dihabiskan di habitat mangrove $T$. palustris tersebut dijumpai pada lantai hutan di bawah akar-akar tanaman mangrove di bagian tengah hingga bagian belakang hutan mangrove. Kemudian pada penelitian yang di lakukan oleh Fratini et al. (2004) menemukan bahwa T. palustris dengan ukuran lebih dari $6 \mathrm{~cm}$ (dewasa) secara aktif mengonsumsi daun mangrove.

Penelitian yang dilakukan oleh Fratini et al. (2001) mengemukakan bahwa T. palustris merupakan spesies yang aktif baik dalam keadaan air laut pasang maupun keadaan ketika air laut surut. Meskipun memiliki kemampuan layaknya amphibi, T. palustris lebih menyukai kondisi lingkungan yang basah yaitu kawasan Hutan Magrove. Siput ini dapat ditemukan di batang dan akar pohon mangrove, di substrat berlumpur dan ter- kadang di daerah berbatu di sekitar tepi laut, disamping itu T.palustris juga memiliki peranan penting dalam menjaga keseimbangan ekologi (rantai makanan), hutan mangrove Teluk Mandeh berada di daerah pesisir dan memiliki sumberdaya hayati perikanan serta vegetasi hutan mangrove.

Isnaningsih dan Pastria (2018) mengemukakan bahwa pada ekosistem mangrove di Tanjung Lesung, T. palustris dewasa banyak dijumpai pada zonasi bagian tengah hingga belakang hutan mangrove, sedangkan $T$. palustris yang masih juvenil terlihat hidup di bagian depan hutan mangrove pada daerah perairan yang berbatasan dengan laut. Aktifitas penguraian serasah oleh T.palustris di hutan mangrove Tanjung Lesung, tidak teramati karena pada saat penelitian dilaksanakan, lokasi tersebut tengah berada pada musim kemarau panjang sehingga moluska mangrove terutama $T$. palustris berada pada fase in-aktif. Namun demikian, moluska yang hidup di daerah intertidal memiliki sifat thermotolerant sehingga mampu menyesuaikan sistem metabolisme tubuhnya termasuk bertahan dengan aerial respirasi saat suhu meningkat di musim kemarau (Taglialoro et al., 2013).

Menurut Houbrick (1991); Pape et al. (2008) Terebralia palustris diketahui memang memiliki segregasi zonasi antara populasi juvenil dan dewasa. Pemisahan zonasi ini terkait dengan kebutuhan pakan yang berbeda antara fase juvenil dan fase dewasa. Perkembangan organ radula $T$. palustris saat fase juvenil hanya memungkinkan spesies ini mengonsumsi detritus yang banyak terdapat di bagian depan hutan mangrove. Setelah memasuki fase dewasa dan struktur radula telah berkembang, maka $T$. palustris akan bermigrasi ke zona bagian tengah hingga belakang hutan mangrove dan mampu memakan materi-materi serasah seperti daundaun, propagul, dan buah tanaman mangrove (Slim et al., 1997).

Studi yang mendalam mengenai gastropoda $T$. palustris yang berasosiasi di kawasan mangrove Teluk Mandeh masih belum pernah dilakukan. Sedangkan Kawasan ini sudah sejak lama menjadi tempat berlangsungnya aktivitas masyarakat yang meliputi kegiatan penangkapan ikan dan menjadi jalur transportasi laut, sehingga berbagai aktivitas tersebut memberikan 
pengaruh terhadap kondisi biota perairan. Seperti hilangnya habitat organisme dan penebangan hutan juga menyebabkan berkurangnya sumber makanan bagi organisme, penangkapan yang terjadi terusmenerus pada ukuran dewasa yang menyebabkan kesempatan untuk berkembangbiak menjadi berkurang di kawasan mangrove Teluk Mandeh ini, maka penulis tertarik melakukan penelitian mengenai struktur populasi $T$. palustris pada ekosistem mangrove Teluk Mandeh Kabupaten Pesisir Selatan Provinsi Sumatera Barat

\section{Metode Penelitian}

\subsection{Waktu dan Tempat}

Penelitian ini telah dilaksanakan pada bulan November 2020. Lokasi penelitian berada di kawasan hutan mangrove Teluk Mandeh Kabupaten Pesisir Selatan Provinsi Sumatera Barat (Gambar 1).
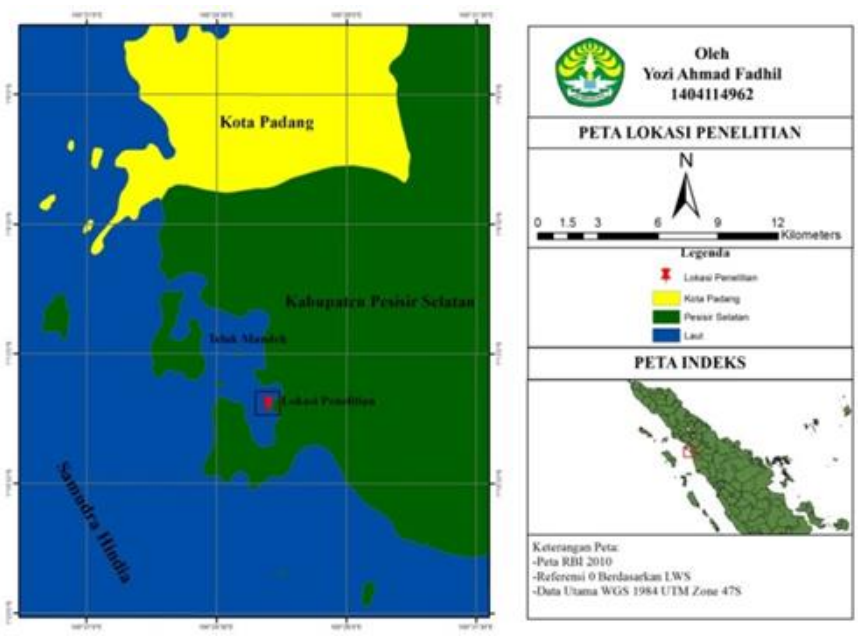

Gambar 1. Kawasan Hutan Mangrove Teluk Mandeh Kabupaten Pesisir Selatan Provinsi Sumatera Barat

\subsection{Metode Penelitian}

Metode yang digunakan dalam penelitian ini adalah metode survei, yaitu melakukan pengambilan sampel T. palustris, sedimen dan pengukuran kualitas perairan langsung di lapangan dan dilanjutkan dengan analisis di laboratorium.

\subsection{Prosedur Penelitian}

\subsubsection{Penentuan Stasiun Pengamatan dan} Pengambilan Sampel T. palustris

Penentuan satsiun penelitian dilakukan dengan teknik purposive sampling, yaitu penentuan lokasi berdasarkan kondisi dan keadaan daerah penelitian. Stasiun penelitian ditentukan dengan cara menarik garis tegak lurus dari batas surut ke arah laut yang dimana masing-masing stasiun memiliki karakteristik yang berbeda yaitu: Stasiun I hutan mangrove yang berada di dekat permukiman warga desa Sungai Nyalo. Stasiun II hutan mangrove yang berada di kawasan objek wisata Punncak Mandeh dan Stasiun III hutan mangrove yang berada jauh dari aktivitas penduduk
Pengambilan sampel T. palustris dibagi menjadi 3 stasiun. Setiap stasiun terdiri atas 3 transek dan setiap garis transek diletakkan petakan kuadrat ukuran $1 \mathrm{~m}$ x $1 \mathrm{~m}$ sebanyak 5 petakan/zona dengan jarak antara petakan 10 meter dapat dilihat pada Lampiran 3. Sampel T. palustris yang diambil semua ukuran pada permukaan sedimen dengan cara sedimen dikeruk sedalam 1-3 cm lalu sedimen di saring menggunakan ayakan $1 \mathrm{~mm}$, sedangkan pengambilan sampel $T$. palustris pada akar dan batang pohon mangrove diambil langsung menggunakan tangan. Setelah itu sampel dimasukkan ke dalam kantong plastik ditambahkan larutan formalin $10 \%$ untuk mengawetkan yang kemudian diberi label (stasiun, transek dan plot) sebelum dibawa ke laboratorium.

\subsubsection{Pengambilan Sampel Sedimen dan Analisis Bahan Organik Sedimen \\ Pengambilan sampel sedimen untuk penentuan kandungan bahan organik sedimen dan tipe sedimen. Dalam pengambilan sampel sedimen, sampel yang diambil pada setiap}


stasiun yaitu hanya satu transek dengan 5 zona saja tanpa pengulangan dimana zona tersebut terletak pada upper zone, middle zone dan lower zone. Sampel sedimen diambil dengan menggunakan sekop sebanyak $\pm 500 \mathrm{~g}$ berat basah dan kemudian dimasukkan ke dalam kantong plastik yang telah diberi label berdasarkan titik samplingnya, sampel dimasukkan ke dalam ice box dan selanjutnya dibawa ke laboratorium untuk dianalisis.

Untuk mengetahui konsentrasi bahan organik pada sedimen dilakukan dengan metode Loss on Ignition (Mucha et al., 2003) yaitu, sampel sedimen yang telah diaduk rata dan telah ditimbang dimasukkan ke dalam cawan yang terbuat dari aluminium foil sebanyak \pm 50 g. Selanjutnya dimasukkan ke dalam oven pada suhu $105^{\circ} \mathrm{C}$ sampai sedimen benar-benar kering, dinginkan ke dalam desikator selama 30 menit kemudian ditimbang, lalu sampel dalam cawan dibakar dengan furnace dalam suhu $550^{\circ} \mathrm{C}$ selama 3 jam dan setelah dinginkan dan timbang dengan timbangan analitik.

Untuk mengetahui kandungan bahan organik total pada sedimen dilakukan dengan rumus yang mengacu pada Mucha et al. (2003), sebagai berikut :

Keterangan :

$$
\mathrm{Li}=\frac{\mathrm{Wo}_{\mathrm{o}}-\mathrm{Wt}}{\mathrm{Wo}_{\mathrm{t}}} \times 100
$$

$$
\begin{aligned}
\mathrm{Li}= & \text { Bahan Organik }(\%) \\
\mathrm{Wo}= & \text { Berat setelah pengeringan pada suhu } \\
& 105^{\circ} \mathrm{C} / \text { sebelum pembakaran }(\mathrm{g}) \\
\mathrm{Wt}= & \text { Berat setelah pembakaran pada suhu } \\
& 550^{\circ} \mathrm{C}(\mathrm{g})
\end{aligned}
$$

\subsubsection{Pengukuran Parameter Kualitas Perairan \\ Parameter lingkungan yang diukur} meliputi parameter kualitas perairan sebagai data pendukung. Kandungan bahan organik pada sedimen dan tipe sedimen juga dianalisis untuk gambaran kondisi kualitas perairan. Pengukuran parameter lingkungan di lakukan setiap stasiun pada saat pasang air laut dengan 3 kali pengulangan. Parameter Kualitas air yang diukur meliputi: suhu, salinitas dan derajat keasaman $(\mathrm{pH})$ air.

\subsubsection{Analisis Tipe Pasir dan Kerikil}

Sampel sedimen diletakkan pada cawan kemudian ditimbang berat basahnya, $\pm 100 \mathrm{~g}$ untuk setiap sampel dengan menggunakan timbangan analitik. Sampel basah dikeringkan dengan menggunakan oven pada suhu $105{ }^{\circ} \mathrm{C}$ sampai tidak ada lagi kandungan airnya. Kemudian sampel ditempatkan dalam beaker glass, tambahkan larutan Hidrogen Peroksida 3\% secukupnya, ayak sampel menggunakan ayakan bertingkat untuk mendapatkan tipe sedimen yang berbeda sesuai dengan ukurannya masingmasing. Sampel yang tertahan pada masingmasing tingkat ayakan dipindahkan kedalam wadah yaitu aluminium foil yang telah diberi label, sementara yang masih lolos ditempatkan dalam tabung silinder untuk analisis tipe lumpur. Tipe sampel pasir yang didapat sesuai ukuran mesh size dikeringkan dengan menggunakan oven. Setelah kering ditimbang berat masing-masing sampel. Data yang dihasilkan dianalisis menggunakan segitiga shepard.

\subsubsection{Analisis Tipe Lumpur}

Sedimen yang lolos dari saringan bersama airnya ditampung dalam sebuah wadah lalu masukkan ke dalam tabung silinder berukuran $1000 \mathrm{ml}$. Sampel diaduk kemudian ambil menggunakan pipet volumetrik dengan batas yang telah ditentukan pada menit ke 5, 15, 30 setelah itu masukkan ke dalam wadah aluminium foil. Sampel kemudian dimasukkan ke dalam oven dan dikeringkan selama 24 jam. Berat sampel yang telah kering dihitung beserta berat wadahnya.

\subsection{Parameter yang Diamati \\ 2.4.1. Kepadatan dan Pola Distribusi T.palustris}

Sampel T. palustris yang diperoleh diamati dan diukur panjangnya di laboratorium. Kepadatan gastropoda dinyatakan sebagai jumlah individu/area. Rumus kepadatan dapat dihitung dengan menggunakan rumus (Soegianto, 1994) sebagai berikut:

$$
\mathrm{D}=\frac{\mathrm{n}}{\mathrm{A}}
$$

Keterangan :

$$
\begin{array}{ll}
\mathrm{D} & =\text { kepadatan individu } \\
\mathrm{n} & =\text { jumlah total individu } \\
\mathrm{A} & =\text { luas total habitat yang disampling }
\end{array}
$$

Untuk mengetahui pola distribusi T.palustris di Teluk Mandeh digunakan Indeks Pola sebaran gastropoda dihitung 
dengan metode perhitungan dengan Indeks Penyebaran Morisita (Soegianto, 1994) sebagai berikut:

$$
\mathrm{Id}=\mathrm{n} \frac{\sum \mathrm{X}^{2}-\mathrm{N}}{\mathrm{N}(\mathrm{N}-1)}
$$

Keterangan :

Id = Indeks Penyebaran

$\mathrm{n} \quad=$ jumlah plot

$\mathrm{N} \quad=$ jumlah individu dalam $\mathrm{n}$ plot

$\sum \mathrm{X}^{2}=$ jumlah kuadrat individu/ plot

\subsubsection{Distribusi Ukuran T. palustris}

Untuk mendapatkan kelas ukuran panjang $T$. palustris yang ditemukan, maka dibuat kelas interval menurut Nugroho et al. (2009), dengan rumus :

$$
k=1+3,322 \log n
$$

Keterangan :

$$
\begin{aligned}
& \mathrm{k}=\text { banyak kelas } \\
& \mathrm{n}=\text { banyak data }
\end{aligned}
$$

\subsection{Analisis Data}

Data yang diperoleh berupa nilai kepadatan, pola distribusi dan distribusi ukuran, selanjutnya data disajikan dalam bentuk tabel dan grafik dan dibahas secara deskriptif. Untuk membandingkan kepadatan T. palustris antar stasiun penelitian dilakukan pengujian statistik dengan uji anova.

\section{Hasil dan Pembahasan}

\subsection{Parameter Kualitas Perairan}

Teluk mandeh merupakan salah satu daerah di Kabupaten Pesisir Selatan Provinsi Sumatera Barat yang berada pada $1^{\circ} 11^{\prime} 21^{\prime \prime}$ LS dan $100^{\circ} 24^{\prime} 01^{\prime \prime}$ BT dengan Luas daratan 15.620 Ha dengan perairan laut seluas 18.650 Ha. Hasil pengukuran kualitas perairan di Hutan Mangrove Teluk Mandeh dapat dilihat pada Tabel 1 .

Tabel 1. Pengukuran kualitas perairan

\begin{tabular}{cccc}
\hline \multirow{2}{*}{ Stasiun } & \multicolumn{3}{c}{ Parameter } \\
\cline { 2 - 4 } & $\mathbf{p H}$ & Salinitas $(\mathbf{p p t})$ & $\mathbf{S u h u}\left({ }^{\mathbf{0}} \mathbf{C}\right)$ \\
\hline 1 & 7 & 29 & 32 \\
2 & 6 & 29 & 31 \\
3 & 7 & 30 & 31 \\
\hline
\end{tabular}

Tabel 1 dapat dilihat rata-rata parameter kualitas perairan pada setiap stasiun yang diukur pada Hutan Mangrove Teluk Mandeh yaitu derajat keasaman $(\mathrm{pH})$ berkisar 6-7, untuk salinitas berkisar 29-30 ppt dan pada suhu berkisar $31-32^{\circ} \mathrm{C}$. Dari nilai yang didapat menjelaskan bahwa $\mathrm{pH}$, salinitas dan suhu relatif konstan di semua stasiun pengamatan.

Hasil pengukuran suhu pada setiap stasiun yang didapat dengan nilai berkisar 31$32^{\circ} \mathrm{C}$ menunjukkan suhu optimum gastropoda dapat melakukan proses metabolism secara optimal. Munarto (2010) yang menjelasakan bahwa suhu sangat berpengaruh terhadap proses metabolisme suatu organisme, gastropoda dapat melakukan proses metabolisme secara optimal pada kisaran suhu antara $25-32^{\circ} \mathrm{C}$, perubahan suhu berpengaruh terhadap jenis organisme yang dapat hidup dan bertahan pada wilayah perairan tertentu, serta aktivitas suatu organisme.

Derajat keasaman $(\mathrm{pH})$ hasil pengukuran $\mathrm{pH}$ yang didapat pada setiap stasiun berkisar 6-7 yang menunjukan kisaran $\mathrm{pH}$ yang baik untuk pertumbuhan gastropoda yang baik sesuai dengan pendapat Dahuri (2003) gastropoda dapat bertumbuh dengan baik pada kisaran pH 6-7. Ariska (2012) menambahkan bahwa nilai $\mathrm{pH}$ yang rendah menyebabkan menurunnya jumlah oksigen terlarut pada suatu perairan, sehingga menyebabkan aktivitas pernapasan gastropoda meningkat dan selera makan menurun. Hal sebaliknya terjadi pada perairan yang memiliki nilai $\mathrm{pH}$ yang tinggi dapat menyebabkan kadar amonia meningkat, sehingga secara tidak langsung telah membahayakan organisme yang berada pada perairan tersebut.

Faktor berikutnya yang juga penting adalah salinitas, salinitas adalah jumlah garam terlarut dalam 1000 gram air laut. Salinitas menggambarkan padatan total dalam air setelah karbonat dikonversi menjadi oksida, semua bromida dan iodida digantikan oleh klorida dan semua bahan organik yang telah dioksidasi. Pada lokasi penelitian terlihat jelas bahwa pengukuran salinitas pada setiap stasiun yang di dapat bekisar 29-30 ppt.

Apabila dilihat dari kisaran salinitasnya maka dapat dikatakan bahwa salinitas pada hutan mangrove Teluk Mandeh sangat ideal untuk pertumbuhan biota-biota laut, seperti gastropoda. Ariska (2012) menyatakan bahwa Gastropoda umumnya mentoleransi salinitas berkisar antara 25-40 ppt. Karena pengaruh salinitas secara tidak langsung mengakibatkan adanya perubahan komposisi dalam suatu ekosistem. 


\subsection{Bahan Organik Sedimen}

Onrizal et al. (2009) melaporkan bahwa kelas gastropoda yang banyak ditemukan pada hutan mangrove kemungkinan disebabkan oleh tingginya bahan organik sebagai sumber makanan bagi gastropoda. Sumber utama bahan organik tanah berasal dari daun, ranting, cabang, batang dan akar tumbuhan. Untuk perbedaan analisis bahan organik sedimen setiap stasiun Hutan Mangrove Teluk Mandeh dapat dilihat pada Gambar 2.

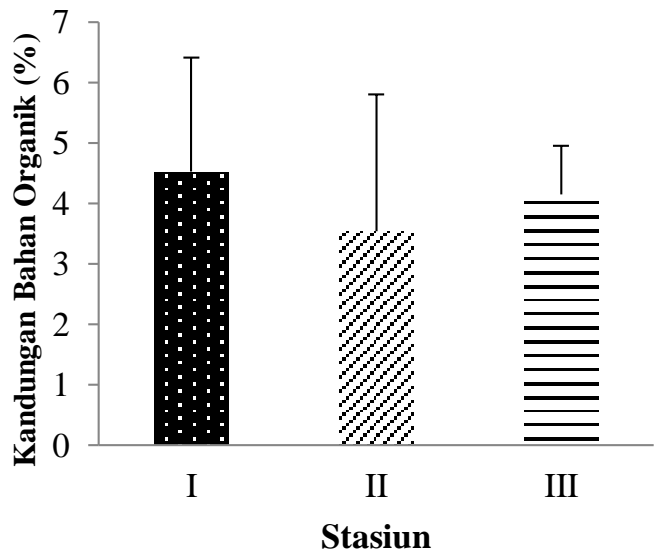

Gambar 2. Kandungan Bahan Organik Sedimen setiap stasiun Hutan Mangrove Teluk Mandeh
Rata-rata bahan organik sedimen tertinggi terdapat pada stasiun I yaitu $4,52 \%$ yang tergolong tinggi sesuai dengan pernyataan Sitorus (2008) yang menyatakan bahwa kriteria tinggi rendahnya kandungan organik sedimen berdasarkan persentase sebagai berikut : $\angle 1 \%=$ sangat rendah; $1-2 \%$ $=$ rendah; $2,01-3 \%=$ sedang; $3,01-5 \%=$ tinggi; $>5 \%=$ sangat tinggi.

Tingginya bahan organik sedimen pada stasiun I diduga disebabkan oleh stasiun I merupakan lokasi penelitian yang dekat dengan wilayah pemukian penduduk dan juga banya ditumbuhi vegetasi mangrove. Aktivitas yang dilakukan oleh penduduk setempat seperti limbah domestik rumah tangga dan sampah dapat meningkatkan kandungan bahan organik. Penyebab lain tingginya bahan organik pada stasiun I ini juga karena serasah mangrove yang jatuh ke permukaan substrat

\subsection{Tipe Sedimen}

Hasil analisis tipe sedimen yang terdapat di Hutan Mangrove Teluk Mandeh terdiri atas kerikil, pasir dan lumpur. Persentase fraksi sedimen yang tertinggi yaitu kerikil 31,14\% pada zona 5 stasiun I, pasir $30,89 \%$ pada zona 3 stasiun III dan lumpur $71,34 \%$ pada zona 5 stasiun II. Hasil analisis tipe sedimen dapat dilihat pada Tabel 2 .

Tabel 2. Analisis Tipe Sedimen

\begin{tabular}{cccccc}
\hline Stasiun & Zona & Kerikil & Pasir & Lumpur & Tipe Sedimen \\
\hline \multirow{6}{*}{ I } & 1 & 22,54 & 14,15 & 63,32 & Lumpur Berkerikil \\
& 2 & 21,68 & 16,66 & 61,57 & Lumpur Berkerikil \\
& 3 & 22,45 & 18,29 & 59,26 & Lumpur Berkerikil \\
& 4 & 27,68 & 15,76 & 56,56 & Lumpur Berkerikil \\
& 5 & 31,14 & 19,87 & 48,99 & Lumpur Berkerikil \\
\hline \multirow{3}{*}{ II } & 1 & 19,01 & 19,15 & 61,84 & Lumpur Berpasir \\
& 2 & 23,76 & 19,92 & 56,32 & Lumpur Berkerikil \\
& 3 & 25,64 & 21,95 & 52,41 & Lumpur Berkerikil \\
& 4 & 28,26 & 19,08 & 52,67 & Lumpur Berkerikil \\
& 5 & 16,57 & 12,09 & 71,34 & Lumpur Berkerikil \\
\hline \multirow{6}{*}{ III } & 1 & 25,1 & 27,19 & 47,71 & Lumpur Berpasir \\
& 2 & 26,08 & 26,72 & 47,21 & Lumpur Berpasir \\
& 3 & 21,2 & 30,89 & 47,92 & Lumpur Berpasir \\
& 4 & 26,25 & 26,79 & 46,96 & Lumpur Berpasir \\
\hline
\end{tabular}

\subsection{Kepadatan Populasi T.palustris}

Nilai rata-rata kepadatan $T$. palustris pada setiap stasiun beragam. Hasil perhitungan rata-rata kepadatan T. palustris di Hutan Mangrove Teluk Mandeh dimana Kepadatan popilasi $T$. palustris pada setiap stasiun berkisar 4,47-6,8 ind $/ \mathrm{m}^{2}$. Kepadatan tertinggi berada pada stasiun I yaitu sebesar $6,8 \mathrm{ind} / \mathrm{m}^{2}$ dan Kepadatan terendah adalah terdapat pada stasiun II yaitu sebesar 4,47 ind $/ \mathrm{m}^{2}$ Untuk melihat lebih jelasnya perbedaan rata-rata Kepadatan $T$. palustris pada masingmasing stasiun di Hutan Mangrove Teluk Mandeh dapat dilihat pada Gambar 3 


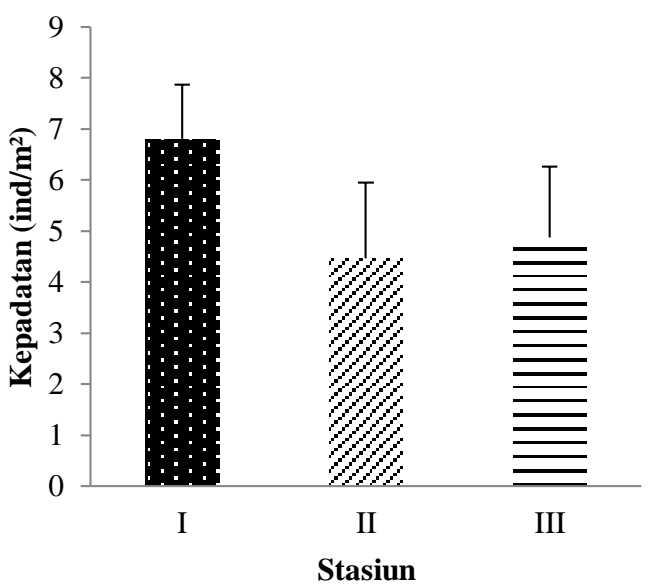

Gambar 3. Kepadatan (ind $/ \mathrm{m}^{2}$ ) Populasi T.palustris antar stasiun di Hutan Mangrove Teluk Mandeh

Stasiun I merupakan lokasi dengan kepadatan paling tinggi yaitu $6,8 \mathrm{ind} / \mathrm{m}^{2}$. Tingginya kepadatan T.palustris pada stasiun I ini diduga kawasan ini memiliki tingkat kandungan bahan organik tertinggi yaitu bernilai 22,59\%. Menurut Hidayanto et al. (2004), semakin besar vegetasi pada hutan mangrove akan memiliki kemampuan besar untuk menghasilkan serasah organik yang merupakan penyusun utama bahan organik dalam tanah.

Sinyo et al (2013), menyatakan bahwa organisme yang memiliki nilai kepadatan tinggi menunjukan bahwa jenis organisme tersebut memiliki kemampuan beradapatasi dengan lingkungan yang ditempatinya, sehingga memiliki kemampuan reproduksi yang tinggi. Lebih lanjut dinyatakan oleh Rahmawati (2014) organisme yang memiliki nilai kepadatan tinggi menunjukan bahwa jenis tersebut memiliki kemampuan menempati ruang yang lebih luas sehingga kesempatan untuk berkembang semakin luas.

Stasiun II merupakan lokasi dengan ratarata kepadatan paling rendah yaitu 4,47 ind $/ \mathrm{m}^{2}$. Rendahnya kepadatan pada lokasi ini keterbukaan lahan pada beberapa zona yang mengakibatkan kondisi lingkungan yang berbeda saat pasang dan saat surut. Sehingga T.palustris di hutan mangrove harus mampu menyesuaikan diri agar dapat bertahan. Beberapa bentuk adaptasi moluska untuk menghindari pasang surut adalah turun ke lantai hutan pada saat surut, dan akan naik kembali ke atas pohon pada saat pasang.
Selama di atas pohon, keong/siput akan menutup rapat operculanya untuk menghindari kekeringan akibat panas (Yona, 2002).

Rendahnya tingkat kepadatan T.palustris pada stasiun II mengakibatkan keterbukaan lahan, sehingga intensitas cahaya matahari lebih banyak. Diduga gastropoda T.palustris kurang mampu untuk beradaptasi di lingkungan tersebut. Hal ini sesuai dengan pendapat Silaen et al. (2013) kepadatan dan distribusi gastropoda dipengaruhi oleh lingkungan habitatnya, ketersediaan makanan, pemangsaan, dan juga kompetisi. Tekanan ekologis dan perubahan lingkungan seperti vegetasi mangrove dapat mempengaruhi kepadatan organisme tersebut.

Rendahnya kepadatan pada stasiun ini dengan tingkat kandungan bahan organik yang juga paling rendah di setiap stasiun dengan nilai $17,63 \%$ hal ini juga di karenakan distasiun ini merupakan kawaasan objek wisata yang dipadati oleh aktivitas manusia dan lokasinya berhadapan langsung dengan laut terbuka.

Berdasarkan penelitian Susiana (2011) bahwa kepadatan $T$. palustris berkisar antara 2-6 ind $/ \mathrm{m}^{2}$, penelitian Pribadi et al. (2009) kepadatan T. palustris di Sapuregel adalah 6,6 ind $/ \mathrm{m}^{2}$ dan penelitian Chusna et al. (2017) kepadatan T. palustris di Yogyakarta adalah 1-2 ind $/ \mathrm{m}^{2}$. Hal ini membuktikan bahwa kepadatan gastropoda pada hutan mangrove Teluk Mandeh yang berkisar 4,47 - 6,8 ind $/ \mathrm{m}^{2}$ tidak berbeda dengan daerah lain. Populasi T.palustris banyak terdapat di akar, batang mangrove serta pohon yang sudah mati. Berdasarkan kepadatan $T$. palustris antar stasiun diperkirakan bahan organik dan tipe sedimen tidak mempengaruhi kepadatan.

\subsection{Pola Distribusi T. palustris}

Nilai pola distribusi $T$. palustris pada setiap stasiun beragam dimana dapat dilihat dari hasil penelitian bahwa hasil perhitungan pola distribusi $T$. palustris antar stasiun di Hutan Mangrove Teluk Mandeh yang didapat memiliki hasil yang berbeda. Hasil pengukuran panjang individu $T$. palustris berkisar antara 2,33-8 $\mathrm{cm}$ yang kemudian dibagi menjadi 8 kelas dapat dilihat pada Gambar 4.

Kelompok ukuran $T$. palustris yang paling banyak ditemui ada pada stasiun I yaitu 
kelompok ukuran 3,04-3,74 $\mathrm{cm}$ yaitu 35 individu dan yang paling rendah pada kelompok ukuran 7,30-8 cm yaitu 1 individu T. palustris. Pada stasiun II, kelompok ukuran yang paling banyak ditemui adalah kelompok ukuran 3,04-3,74 cm yaitu 39 individu sedangkan kelompok ukuran 4,46-5,16 cm hingga 7,30-8 $\mathrm{cm}$ tidak ditemukan individu

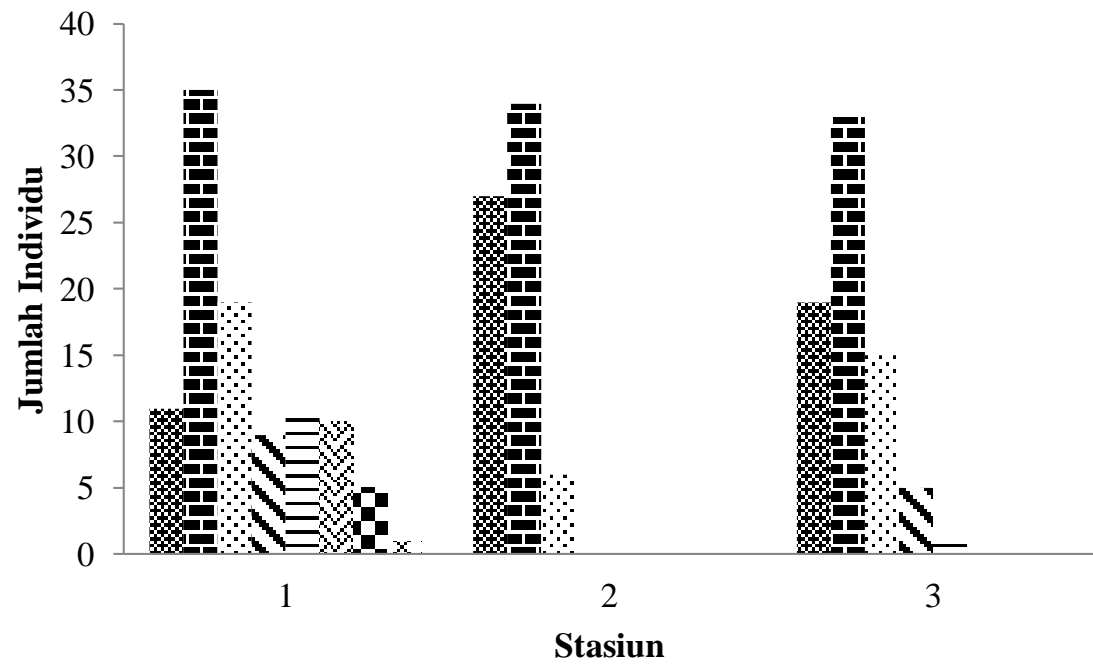

T.palustris. Kemudian pada stasiun III, yang paling banyak ditemukan adalah kelompok ukuran 3,04-3,74 cm yaitu 35 individu, sedangkan kelompok ukuran 5,88-6,58 hingga 7,30-8 $\mathrm{cm}$ tidak ditemukan. Dari tiga stasiun yang diteliti, hanya pada stasiun I yang menempati semua kelompok ukuran.

\section{Gambar 4. Distribusi ukuran $T$. palustris pada setiap stasiun pengamatan di Hutan Mangrove Teluk mandeh}

Berdasarkan hasil penelitian yang didapatkan pola distribusi $T$. palustris di hutan mangrove Teluk Mandeh berkisar 1,00 yang dapat di kategorikan pada $\mathrm{Id}=1$ yaitu penyebaran gastropoda bersifat acak. Pola distribusi ini dapat dipengaruhi oleh faktor kualitas perairan dan adanya persaingan, baik itu persaingan tempat maupun makanan. Hal ini didukung oleh penelitian Suhendra et al. (2017), organisme yang pola penyebaranya seragam disebabkan oleh kondisi lingkungan di suatu areal hampir sama dan persaingan tempat tinggal dan persaingan makanan, sehingga ditemukan hidup tidak berkelompok. Menurut Astari et al. (2018), apabila indeks kurang dari $1 \quad(\mathrm{Id}=1)$ yang menunjukkan bahwa pola distribusi dari bivalvia cenderung acak. Tipe pola sebaran tersebut disebabkan oleh adanya persaingan individu kerang sehingga mendorong pembagian ruang secara rata. Selain itu, faktor lingkungan seperti suhu, $\mathrm{pH}$ dan salinitas juga dalam kisaran optimal sehingga mendukung kehidupan gastropoda.

Menurut Cambell et al. (2004), pola persebaran acak terjadi karena kurang atau tidak adanya tarik menarik atau tolak menolak diantara individu dalam suatu populasi.
Dengan sifat pola sebaran yang acak aktivitas reproduksi akan menjadi rendah dan keberadaan populasi tersebut di alam menjadi lemah atau kurang kokoh.

Menurut Suwondo et al. (2005) mengelompoknya jenis moluska diduga karena sifatnya yang hidup bergerombol, seragam, dan menempel pada satu tempat sepanjang waktu. Pola distribusi yang acak terkait dengan cara hidup yang memilih tempat yang kurang cocok. Pola penyebaran acak berkaitan dengan kondisi lingkungan abiotik (suhu, salinitas) yang berfluktuasi, ketersediaan bahan organik yang tinggi, tipe substrat yang baik dan cocok bagi kehidupan spesies tersebut (Yuniarti, 2012). Bahri (2006) menyatakan bahwa pola distribusi biota dipengaruhi oleh tipe habitat yang meliputi faktor fisika-kimia perairan serta makanan dan kemampuan adaptasi dari suatu biota dalam sebuah ekosistem.

Kelompok ukuran $T$. palustris yang paling banyak ditemui ada pada stasiun I yaitu kelompok ukuran 3,04-3,74 cm yaitu 35 individu dan yang paling rendah pada kelompok ukuran 7,30-8 cm yaitu 1 individu T. palustris. Pada stasiun II, kelompok ukuran yang paling banyak ditemui adalah kelompok 
ukuran 3,04-3,74 $\mathrm{cm}$ yaitu 39 individu sedangkan kelompok ukuran 4,46-5,16 cm hingga 7,30-8 $\mathrm{cm}$ tidak ditemukan individu T.palustris. Kemudian pada stasiun III, yang paling banyak ditemukan adalah kelompok ukuran 3,04-3,74 cm yaitu 35 individu, sedangkan kelompok ukuran 5,88-6,58 hingga 7,30-8 $\mathrm{cm}$ tidak ditemukan. Dari tiga stasiun yang diteliti, hanya pada stasiun I yang menempati semua kelompok ukuran.

Tingginya frekuensi distribusi kelompok ukuran sedang yang ditemukan diduga karena kelompok tersebut memiliki daya adaptasi yang tinggi dan dapat menghindari predator dibandingkan dengan kelompok ukuran yang kecil. Rendahnya kelompok ukuran besar diduga diambil oleh masyarakat untuk memenuhi kebutuhan sehari-hari. Berbedanya tingkat distribusi ukuran mengindikasikan tentang ketersediaan nutrien dan bahan makanan yang berbeda.

Keberadaan $T$. palustris ukuran besar hingga yang terkecil disebabkan oleh kondisi tipe substrat yang tidak cocok untuk gastropoda dewasa maupun muda. Tipe substrat setiap stasiun penelitian yang mendominan adalah lumpur berkerikil sedangkan gastropoda dewasa lebih menyukai tempat dengan tipe substrat lumpur berpasir pada tempat yang terbuka. Gastropoda dengan ukuran besar akan lebih memilih tempat yang mudah dan cepat untuk mendapatkan makanan. Tipe substrat lumpur berpasir akan memudahkan gastropoda ukuran besar mendapatkan suplai nutrisi dengan cara menyaring nutrisi tersebut.

Hal ini sesuai dengan pernyataan Pratikto dan Rochaddi (2006) bahwa gastropoda yang masih muda hidup pada bagian hutan mangrove dengan kondisi substrat dasar berlumpur sedangkan yang dewasa lebih menyukai pada daerah yang terbuka dengan substrat lumpur berpasir. Selain itu masyarakat juga mengambil beberapa jenis gastropoda ukuran besar untuk dijadikan bahan makanan. T. palustris memiliki nilai kelimpahan tertinggi karena substrat dasar pada stasiun pengamatan sangat baik untuk spesies ini. Substrat dasar pada stasiun penelitian adalah lumpur berpasir dan lumpur berkerikil yang merupakan habitat yang baik bagi $T$. palustris. Tipe substrat berlumpur merupakan tempat yang stabil bagi gastropoda. selain itu pada tipe substrat berlumpur banyak mengandung bahan organik yang merupakan sumber makanan bagi gastropoda.

\section{Kesimpulan dan Saran}

Berdasarkan hasil penelitian Terebralia palustris pada setiap stasiun di hutan mangrove Teluk Mandeh ini adalah tinggi dimana kepadatan ini menggambarkan kepadatan secara umum di kawasan mangrove, hasil penelitian untuk pola distribusi $T$. palustris pada setiap stasiun di hutan mangrove Teluk Mandeh adalah penyebaran bersifat acak sedangkan kelompok ukuran $T$. palustris di setiap stasiun pada hutan mangrove Teluk Mandeh berukuran hingga $8 \mathrm{~cm}$.

Pada penelitian ini hanya menggambarkan kepadatan dan pola distribusi populasi secara umum. Diharapkan untuk penelitian ke depannya agar dapat meneliti jenis gastropoda yang lain dan jenis gastropoda $T$. palustris dengan ukuran yang lebih dari yang didapat dari penelitian ini.

\section{Daftar Pustaka}

Ariska. (2012). Keanekaragaman dan Distribusi Gastropoda dan Bivalvia (Moluska) di Muara Karang Tirta Pangandaran. Skripsi. Institut Pertanian Bogor. Bogor.

Astari, F.D., A. Solichin, dan N. Widyorini. (2018). Analisis Kelimpahan, Pola Distribusi, dan Nisbah Kelamin Kerang Kijing (Anodonta woodiana) di Inlet dan Outlet Danau Rawapening Jawa Tengah. Management of Aquatic Resources Journal, 7 (2) : 227-236.

Baharuddin, N., N.B. Basri and N.H. Syawal. (2018). Marine Gastropods (Gastropoda; Mollusca) Diversity and Distribution on Intertidal Rocky Shores of Terengganu, Peninsular Malaysia. AACL Bioflux, 11(4) : 1144 - 1155.

Bahri, F.Y. (2006). Kenaekaragaman dan Kepadatan Komunitas Moluska di Perairan Sebelah Utara Danau Maninjau. Skripsi. Institut Pertanian Bogor. Bogor

Budiman, A. (2009). Persebaran dan Pola Kepadatan Moluska di Hutan Bakau, Berita Biologi, 9(4) : 403 - 409.

Chusna, R.R.R., S. Rudiyanti dan Suryanti. (2017). Hubungan Substrat Dominan 
dengan Kelimpahan Gastropoda pada Hutan Mangrove Kulonprogo, Yogyakarta. Saintek Perikanan (Indonesian Journal of Fisheries Science and Technology), 13 (1): 19-23.

Dahuri, R. (2003). Keanekaragaman Hayati Laut: Aset Pembangunan Berkelanjutan Indonesia. Gramedia Pustaka Utama. Jakarta.

Dinas Kelautan dan Perikanan Kabupaten Pesisir Selatan Kota Padang Provinsi Sumatera Barat. 2011.

Fratini, S., S. Cannicci, dan M. Vannini. (2001). Feeding Clusters and Olfaction in the Mangrove Snail Terebralia palustris (Linnaeus) (Potamididae: Gastropoda). Journal of Experimental Marine Biology and Ecology, 261 : 173-183.

Fratini, S., V. Vigiani, S. Cannicci, dan M. Vannini. (2004). Terebralia palustris (Gastropoda Potamididae) in a Kenyan mangal: size structure, distribution and impact on the consumption of leaf litter. Marine Biology, 144: 1173-1182.

Hirzan, R., I.J. Zakaria, Izmiarti. (2017). Dipersitas Gastropoda pada Akar Mangrove di Pulau Sarindah, Padang, Sumatera Barat. Jurnal Biologi Universitas Andalas, 5(1): 24-40.

Holland, J. S. (2008). Living Color of Mollusca. National Geographic, (6): 86-92.

Houbrick, R.S. (1991). Systematic review and functional morphology of the mangrove snails Terebralia and Telescopium (Potamididae: Prosobranchia). Malacologia, 33: 289- 338

Islami, M.M. (2010). Beberapa Aspek Biologi Ordo Nudobranchia. Jakarta. Journal of Oceana, (35).

Isnaningsih. N.R. dan M.P. Patria. (2018). Peran Komunitas Moluska dalam Mendukung Fungsi Kawasan Mangrove di Tanjung Lesung Pandeglang, Banten. Jurnal Biotropik, 6(2) : 85-93

Mucha, A.P., M.T.S.D. Vasconcelos, dan A.A. Bordalo. (2003). Macrobentic Community in The Douro Estuary Relation with Trace Metals and Natural Sediment Characteristic. Environment Pollution, 121: 160-180.

Munarto. (2010). Studi Komunitas Gastropoda di Situ Salam Kampus
Universitas Depok. Skripsi. Depok: Universitas Indonesia.

Nugroho, F., V. Amrifo dan R. Taibin. (2009). Buku Ajar Statistika Dasar (Edisi Revisi). Pusaka Riau. Pekanbaru.

Onrizal., F.S.P. Simarmata dan H. Wahyuningsih. (2009). Keanekaragaman Makrozoobenthos pada Hutan Mangrove yang Direhabilitasi di Pantai Timur Sumatera Utara. Jurnal Natur Indonesia, 11 (2) : 94-103.

Pape, E., A. Muthumbi, C.P. Kamanu, A. Vanreusel. (2008). Size-dependent distribution and feeding habits of Terebralia palustris in mangrove habitats of Gazi Bay, Kenya. Estuarine, Coastal and Shelf Science, 76: 797-808.

Praktikto, I., dan B. Rochaddi. (2006). Ekologi Perairan Delta Wulan Demak Jawa Tengah: Korelasi Sebaran Gastropoda dan Bahan Organik Dasar di Kawasan Mangrove. Jurnal Ilmu Kelautan, 11(4): 216 - 220

Pribadi, R., R. Hartati dan C.A. Suryono. (2009). Komposisi Jenis dan Distribusi Gastropoda di Kawasan Hutan Mangrove Segara Anakan Cilacap. Jurnal Ilmu Kelautan, 14 (2): 102-111.

Rivai, A. P., Zulkifli., S. Nasution. (2018). Hubungan Kerapatan Lamun (Thalassia hemprichii) dengan Kepadatan Gastropoda di Perairan Pantai Nirwana Kota Padang Sumatera Barat. Skripsi. Universitas Riau. Riau.

Silaen, I.F., B. Hendrarto dan M. N. Supardjo. (2013). Distribusi dan Kepadatan Gastropoda pada Hutan Mangrove. Journal of Management of Aquatic Resources, 2 (3): 93-103.

Sinyo. (2013). Studi Kepadatan dan Keanekaragaman Jenis Organisme Bentos pada Daerah Padang Lamun di Perairan Pantai Keluruhan Kastela Kecamatan Pulau Ternate: Unkhair Ternate.

Sitorus, D.B.R. (2008). Keanekaragaman dan Distribusi Bivalvia serta Kaitannya dengan Faktor Fisik-kimia di Perairan Pantai Labu Kabupaten Deli Serdang. Tesis. Universitas Sumatra Utara. Medan.

Slim, F. J., M.A. Hemminga, C. Ochieng, N. T. Jannink, E. Cocheret de la Morinière dan G. van der Velde. (1997). Leaf 
litter removal by the snail Terebralia palustris (Linneaus) and sesarmid crabs in an East African mangrove forest (Gazi Bay, Kenya). Journal of Experimental Marine Biology and Ecology, 215: 35-48.

Soegianto, A. (1994). Ekologi Kuantitatif: Metode Analisis Populasi dan Komunitas. Penerbit Usaha Nasional. Surabaya.

Suhendra, I., Bahtiar., D. Oetama. (2017). Studi Distribusi dan Kepadatan Kerang Pasir (Modiolus modulaides) di Perairan Pulau Bungkutoko Kecamatan Abeli Kota kendari Sulawesi Tenggara. Jurnal Manajemen Sumberdaya Perairan, 2 (3) : 179-187

Susiana. (2011). Diversitas dan Kerapatan Mangrove, Gastropoda dan Bivalvia di Estuari Perancak, Bali. Skripsi. Fakultas Ilmu Kelautan dan Perikanan. Universitas Hasanuddin. Makassar.

Suwondo, E. Febrita, dan F. Sumanti. (2005). Struktur Komunitas Gastropoda pada Hutan Mangrove di Pulau Sipora Kabupaten Kepulauan Mentawai Sumatera Barat.
Taglialoro, M., J. Clavier, L. Chauvaud, J. Grall. (2013). Carbon Emission associated with respiration and calcification of nine gastropod species from the intertidal rocky shore of Western Europe. Marine Biologi, 160: 2891- 2901

Wijayanti, H. (2007). Kualitas Perairan di Pantai Kota Bandar Lampung Berdasarkan Komunitas Hewan Makrobenthos. Tesis. Program Pascasarjana.Universitas Diponegoro. Semarang.

Yuniarti, N. (2012). Keanekaragaman dan Distribusi Bivalvia dan Gastropoda (Moluska) di Pesisir Glayem Juntinyuat, Indramayu, Jawa Barat. Skripsi. Departemen Biologi Fakultas Matematika dan Ilmu Pengetahuan Alam. Institut Pertanian Bogor. Bogor 